Zbornik Instituta za kriminološka

i sociološka istraživanja

2020 / Vol. XXXIX / 2-3 / 127-142

Pregledni naučni rad

Primljeno: 12. jula 2020. godine

Prihvaćeno: 12. avgusta 2020. godine

DOI: $10.47152 /$ ziksi2020238

UDK: $343 \cdot 971: 174.6$

\title{
KOCKANJE KAO KRIMINOGENI FAKTOR
}

\author{
Slađana Milošević ${ }^{*}$ \\ Višnja Miloševićc*
}

\begin{abstract}
Cilj ovog rada je sagledavanje odnosa između kockanja kao već razvijene zavisnosti s jedne strane $i$ kriminalnih ponašanja $s$ druge strane. $U$ radu su najpre prikazana teorijska stanovišta $i$ shvatanja prirode odnosa kockanja i kriminaliteta kao i nekoliko modela koji pokazuju u kojoj meri i na koji način kockanje doprinosi određenom kriminalnom ponašanju. Podaci različih istraživanja poturđuju da se kriminogeno dejstuo kockanja može izdvojiti kod pojedinih vrsta kriminaliteta. Najčešća vrsta prestupništva povezana sa kockanjem su finansijski motivisana krivična dela kao što su krađe, prevare, pronevere, zatim nasilje u porodici, maloletnička $i$ saobraćajna delinkvencija. Sagledavanje rezultata, takođe, ukazuje na kompleksnu relaciju odnosa kockanja i kriminaliteta, te da ovom kriminogenom faktoru treba posvetiti više pažnje naročito u domaćim kriminološkim istraživanjima.
\end{abstract}

KLJUČNE REČI: kockanje / kriminogeni faktor / kriminalitet / nasilje

* Institut za mentalno zdravlje, Beograd. E-mail: sladjanamilo@gmail.com

* Student MA studija Pravnog fakulteta Univerziteta u Beogradu. E-mail: visnja19995@gmail.com 


\section{UVOD}

Za većinu ljudi kockanje predstavlja slobodnu svakodnevnu opuštajuću aktivnost koja sa sobom ne nosi nikakve negativne posledice. Sve veća dostupnost ,igara na sreću“, uključujući i kockanje putem interneta, masovnost, doprinela je da kockanje danas predstavlja opšte prihvaćenu multidimenzionalnu društvenu pojavu (Bjelajac, 2017). Upravo je dostupnost kockanja dovela do ekspanzije kockanja u mnogim zemljama, što s jedne strane ne iznenađuje, uzmemo li u obzir sve naklonjenije stavove javnosti prema kockanju kao jednom obliku zabave, državne interese za stvaranjem novih radnih mesta i povećanjem nacionalnih prihoda, kao i interese lokalnih zajednica da ojačaju turizam i ekonomski razvoj (Binde, 2009; Tse, Hong, Wang \& Williams, 2012). Međutim, s druge strane kod izvesnog broja ljudi kockanje postaje „više“ nego bezopasna zabava koja se duž kontinuuma može kretati od rekreativnog, rizičnog, problematičnog, pa do patološkog ili kompulsivnog (prepoznatog kao oblik zavisnosti) (Ashley \& Boehlke, 2012). U skladu s tim, može se reći kada kockanje preraste u stalni obrazac ponašanja i počne da stvara brojne društvene i individualne posledice, postaje devijacija koja direktno utiče na funkcionisanje pojedinca, njegove porodice, a indirektno i društva u celini (Adolphe et al., 2018; Shaffer \& Korn, 2002; Shaw et al., 2007). Najpre, slabi materijalna moć, gube se materijalna sredstva, kao i osnovna sredstva za život. Sve ovo može podstaći odluku pojedinca za vršenje kriminalnih delatnosti da bi se došlo do novčanih sredstava za dalje kockanje (Subotin, 2018).

Odnos između kockanja kao razvijene zavisnosti s jedne strane i kriminaliteta s druge strane, sve više zaokuplja pažnju stručne, naučne i šire društvene javnosti. Mnoga isrtaživanja su pokazala na postojanje kompleksne veze između kockanja i raznih vrsta kriminalnog ponašanja kao i drugih socijalnih devijacija. Iako postoji konsenzus da je veza ovog odnosa složena, ispitivanje prirode ovog odnosa je i dalje predmet mnogih istraživanja. Konkretnije, da li i u kojoj meri i na koji način kockanje doprinosi izvršenju određenog kriminalnog ponašanja, prekršaja ili nekih drugih devijacija, može li se govoriti o kauzalnom odnosu ili ne? S obzirom na to da veza između kockanja i kriminaliteta podrazumeva interakciju psiholoških, socijalnih, kulturnih i situacionih faktora, neretko su rezultati istraživanja oprečni (Arthur, Williams \& Belanger, 2014; Lind et al., 2015; Kryszajtys \& Matheson, 2017). U vezi sa prethodnom konstatacijom navešćemo nekoliko shvatanja: najpre, zagovornici teze uzročno-posledične veze kriminalne aktivnosti povezane sa kockanjem, ističu kauzalnu vezu kockanja kao uzroka pojedinih vrsta kriminaliteta, dok se kod nekih vrsta kriminaliteta kockanje pojavljuje kao indirektni faktor, zatim kockanje kao dodatni etiološki faktor kriminaliteta (Binde, 2016). Najzad, značajno je istaći i konstataciju da kockanje ne dovodi do vršenja krivičnih dela, tj. tezu koja odbacije uzročno-posledičnu vezu (Aborn, 2005; Lahn \& Grabosky, 2003). Značajna su i istraživanja koja u svom fokusu imaju socijalne aspekte i konsekvence kockanja, odnosno koja nam kroz analizu uticaja kockanja na porodični život zavisnika, njegovu ekonomsku situaciju, rad i radnu sposobnost, kao i neke druge psihosocijalne karakteristike kockara, donose podatke o tzv. Posrednoj ulozi kockanja u genezi kriminaliteta. 
Zbornik IKSI, 2-3/202O - S. Milošević, V. Milošević

„Kockanje kao kriminogeni faktor”, (str. 127-142)

\section{RAZLIČITI PRISTUPI OBJAŠNJENJU PRIRODE VEZE KOCKANJE-KRIMINALITET}

Istraživanje odnosa između kockanja i kriminalnog ponašanja je predmet interesovanja mnogih istraživanja i etioloških pristupa kriminalitetu. Dostupni podaci ukazuju da se kockanje, kao i zavisnost od kockanja (patološko kockanje) javljaju u funkciji kriminogenog faktora koji može da deluje neposredno ili posredno (May-Chahal et al., 2017). Neposredno kriminogeno dejstvo kockanja je, pored imovinskih krivičnih dela, detektovano i u etiologiji nasilja u porodici. Pored nasilnih krivičnih dela između intimnih partnera, članova porodice, neposredni uticaj kocke je uočen i kod drugih nasilnih ponašanja kao što su vandalizam i saobraćajna delinkvencija (Cook et al., 2015). Kauzalni odnos između kockanja i kriminala se može sagledati u vidu pritiska koji gubici stvaraju kod kockara da učini krivično delo koje će omogućiti dohodak u cilju nastavka kockarskih aktivnosti (McCorkle, 2002; Kryszajtys \& Matheson, 2017). U skladu sa tim, kako se frekvenca kockanja povećava, tako je mogućnost za nabavku novca sve manja, iscrpljuju se svi legitimni izvori i pribegava se rizičnim i ilegalnim načinima. Većina kockara poseže za kriminalnim radnjama $u$ „fazi očajanja“, tj. kada nastupe prekomerni gubici i posledice (Bjelajac, 2017; Turner et al., 2013). Podaci ukazuju da u ovoj fazi oko 70\% do $80 \%$ zavisnika od kockanja čine krivična dela poput: prevara, pronevera, krađa, izdavanja čekova bez pokrića, utaje i druga nenasilna krivična dela, da bi pribavili sredstva za nastavak kockanja, neretko obijanje prodavnica i radnji gde postoji „živi“ novac koji može odmah da se upotrebi, krađa predmeta bliskih osoba koje su prodavane ili založene (Bjelajac, 2017; Lambie \& Randell, 2013).

Kada je u pitanju vrsta odnosa, u literaturi se mogu sresti i različita teorijska objašnjenja odnosa između kriminaliteta i kockanja. Evidentno je da se pridaje značaj posrednom i/ili dopunskom uticaju kockanja na nastanak i razvoj kriminalnog ponašanja kod pojedinaca, odnosno kriminaliteta uopšte. U skladu sa tim, predstavljeno je nekoliko mehanizama koji objašnjavaju kako kockanje može uticati na kriminalno ponašanje.

Najpre, u literaturi se mogu pronaći različita teorijska objašnjenja odnosa kockanja i kriminaliteta. Ovaj odnos se može sagledati kroz nekoliko pristupa: individualni, interakcioni, socijalno strukturalni i teorije rutinske aktivnosti.

1) individualni pristup sugeriše da se kriminalna aktivnost povezana sa kockanjem zasniva na modelu racionalnog izbora pojedinca, tj. donošenja odluke o kockanju kao ponašanju koje će doprineti očekivanoj nagradi i trudu u odnosu na rizik. Kockanje je racionalna odluka kojom se povećava „profit“ ili minimizira „gubitak“ i prevazilazi rizik od kazne. Prema teoriji socijalnog učenja koja se zasniva na postulatu da se prestupništvo i drugi oblici ponašanja usvajaju putem rane izloženosti u ovom slučaju kockanju putem roditeljskog učešća ili povećanog pritiska vršnjaka. Posmatranjem njihovih kockarskih aktivnosti i socijalne, psihološke i materijalne nagrade koje time dobijaju, pojedinci stiču pozitivne stavove prema kockanju i ilegalnim aktivnostima. Shodno tome, ako se pojedinci nađu $u$ situacijama koje pogoduju bavljenju tim aktivnostima, oni će verovatno to i učiniti (Banks \& Waugh, 2018; Smith, Wynne \& Hartangel, 2003). 
2) interaktivni pristup ukazuje da je kriminalna aktivnost povezana sa kockom posledica društvenih veza i društvenih odnosa koje oblikuju vulnerabilnost ili rezilijentnost pojedinca. Pojedinac koji ne uspe da uspostavi adekvatne socijalne veze, ili te veze doživljava kao ograničenje u ponašanju, pribegava kockanju kao načinu oslobađanja od tih veza. Tada pojedinac stupa u kompromitovane društvene veze koje ga ohrabruju da učestvuju u nezakonitim aktivnostima -ilegalnom kockanju ili da čine druga krivična dela u cilju podržavanja kockanja kao što je pranje novca, pronevere, prodaja droge.

3) socijalno-strukturalni pristup ukazuje da društvene snage poput nezaposlenosti, deprivacije i društvene vrednosti i podrške određenim grupama podstiču i olakšavaju kockanje i samim tim utiču na distribuciju kriminala i viktimizacije (Banks \& Waugh, 2018; Mishra et al., 2011; Smith et al., 2003; Potenza et al., 2001).

4) teorija rutinske aktivnosti zasniva se na postulatu da se verovatnoća kriminalnih aktivnosti povećava na mestima gde istovremeno postoje i motivisani počinioci i odsustvo formalne kontrole, kada potencijalni ciljevi nadmašuju potencijalni rizik od hapšenja. Konkretno, gotovinska transakcija u kockarnicama predstavlja „magnet“ za organizovani kriminal kojim se ilegalni prihodi od pranja novca uvode u legalne tokove. Međutim, ukoliko je kontrola efikasna, razmatraju se mogućnosti transfera kriminala izvan područja kockarnica (Potenza et al., 2001).

Kada je reč o kriminalnim aktivnostima povezanim sa kockanjem, grubo se mogu podeliti u tri osnovne grupe: integritet kockanja, infiltracija organizovanog kriminala i sekundarni kriminal (Podgornik \& Kovačić, 2013).

- Pretnja integritetu samog kockanja može biti u obliku promene rekvizita za kockanje, aranžmana između samih kockara, aranžmana između kockara i zaposlenih u kockarnici, isplate procenta očekivanog dobitka i drugi oblici prevare.

- Kockanje može biti povezano i sa organizovanim kriminalom kroz kriminogenu prirodu kockanja koja je nasleđe ilegalnog kockanja kroz: pranje novca, iznude, prevare, korupciju javnih službenika koji dodeljuju licence za rad kockarnica, korupcija javnih službenika koji mogu uticati na liberalizaciju zakonske regulative.

- Sekundarni kriminalitet povezan sa kockanjem obuhvata krađe, krađe automobila, pljačke, trgovinu drogom, prostituciju, silovanje.

Pored ovih modela, kada se analizira uzročno-posledični odnos kockanja i kriminalnih aktivnosti, u literaturi se navode kockanjem indukovana krivična dela zasnovana na instrumentalnoj vezi. Prema instrumentalnoj vezi kockanja i kriminalnih aktivnosti, prestupi mogu biti direktno ili indirektno povezani sa kockanjem. Direktni prestupi odnose se na one posebno motivisane željom za pribavljanje novca za kockanje. „Indirektno povezani“ su definisana kao krivična dela motivisana potrebom da se prikriju nedostaci u podmirivanju životnih troškova prouzrokovanih gubicima zbog kockanja. U oba slučaja kriminalne aktivnosti predstavljaju pokušaj nadoknade gubitka usled kockanja i/ili izbegavanja otkrivanja dugova od strane značajnih drugih, s jedne strane i obezbeđivanje sredstava za nastavak kockanja, s druge strane (Adolphe et al., 2018; Lahn \& Grabosky, 2003; May-Chahal et al., 2017; Perrone, Jansons \& Morrison , 2013). 
Brojni drugi autori su saglasni da činjenje krivičnih dela u cilju finansiranja kockarskih aktivnosti treba posmatrati kao pokazatelj ozbiljnosti poremećaja. Štaviše, da se krivična dela retko izvršavaju bez učešća drugih činilaca, u obzir se moraju uzeti psihološki, socijalni, situacioni i interakcija svih navedenih faktora kockanja (Ashley \& Boehlke, 2012; Binde, 2016; Turner et al., 2013).U skladu sa tim, navode posredni model veze između kockanja i kriminaliteta: faktor ličnosti poput impulsivnosti, posebno slaba samokontrola i traženje senzacija su česte odlike zavisnika od kockanja koje determinišu preuzimanje rizika koji pokreće i kriminalno ponašanje, impulsivni stil odlučivanja, visoki nivoi hitnosti i prihvatanje pogrešnih verovanja (da niz gubitaka mora da prati pobeda) pogoršavaju ekonomsku situaciju i samim tim povećavaju prestupničke aktivnosti (Mestre-Bach et al., 2020) i kosimptomatska veza usmerena na posrednički faktor, odnosno farmakološko dejstvo alkohola i drugih psihoaktivnih supstanci sa izraženom disregulacijom spoljašnjeg ponašanja usled smanjene inhibicijske kontrole potencijalnih prestupnika-kockara (Rudd \& Thomas, 2015), kockanje kao deo kriminalnog stila života koje sa uobičajenim faktorima rizika uključuje i vidljivo trošenje novca stečenog na ilegalan način. Kod osoba sklonih krivičnim radnjama postoji intenzivnija potreba za kockanjem koja često proizilazi iz njihove antisocijalne potrebe za uzbuđenjem i brzom zaradom. U ovakvim situacijama kockanje i kriminal su obrasci ponašanja koji uzročno-posledično pojačavaju jedan drugog. Zatim, podjednako su važne i društvene norme, zakonska regulativa i dostupnost kockanja (Turner et al., 2013; Binde, 2016; Lind et al., 2015).

$\mathrm{Na}$ kraju, koenzistencijalna veza zasnovana na slučajnoj vezi u kojoj kriminalne radnje i kockanje nisu direktno povezane, nego su samo u njima učestvovali isti ljudi (Adolphe et al., 2018; Arthur et al., 2014; Lahn \& Grabosky, 2003; Perrone et al., 2013).

Pored prikazanih modela, jedan od posrednih modela predstavljen kroz delo finansijskog kriminaliteta prevare je definisan konceptom „nerazdvojnog modela“ za koji je karakterističan „trougao prevare“, sličan „zločinu sa belim okovratnikom“. Prema ovom modelu, da bi se dogodila prevara i pronevera neophodna su tri elementa: prilika, potreba/pritisak i racionalizacija. Prilika se odnosi na mogućnost pristupa novcu drugih ljudi. Potreba/pritisak je faktor koji pokreće pojedinca da počini krivično delo, u ovom slučaju je to zavisnost od kockanja. Racionalizacija je opravdanje pojedinca za ponašanje, tj. krađu novca kao privremeno pozajmljivanje koje zahteva hitna potreba za novcem (Binde, 2016; Cressey, 1973 prema: Sakurai, Smith \& Graycar, 2003). Prema ovom modelu, kako autori navode, kockar smatra da je uzimanje novca ispravan način, verujući da će dalje kockanjem doći do dobitka koji će omogućiti vraćanje „pozajmljenog“ novca i rešavanje drugih problema uz verovanje da je rizik da bude otkriven mali. 
Zbornik IKSI, 2-3/202O - S. Milošević, V. Milošević

„Kockanje kao kriminogeni faktor”, (str. 127-142)

\section{KOCKANJE I KRIMINALITET NASILJA}

\subsection{Rezultati istraživanja, studija i statistički pokazatelji: iskustva iz sveta}

Iz svega do sada prikazanog, može se zaključiti da u literaturi postoji dovoljno dokaza o povezanosti kockanja i različitih vidova kriminaliteta. Međutim, neophodno je istaći da je između dostupnih podataka neretko teško izvršiti komparaciju i analizu, s obzirom na to da se ne prikupljaju sistematski, nego se do njih dolazi primenom različitih metoda i tehnika (npr. analizom zvanične statistike državnih organa, policijskih i sudskih predmeta, primenom anketa o viktimizaciji i samoprijavljivanjem) (Folino \& Abait, 2009; Smith \& Simpson 2014; Stitt, Nichols \& Giacopassi, 2003). Takođe, treba imati i na umu da se često zaobilazi prijava policiji za finansijska krivična dela, nego se interno rešavaju na nivou korporacije, porodice (Adolphe et al., 2018; Sakurai et al., 2003). Kada se navedeni faktori uzmu u obzir, postaje jasnije zbog čega je prikupljanje podataka otežano i zašto je teško precizno predstaviti razmere ovog problema, kao i da svaki od ovih faktora može uticati na „prebojavanje“ dobijenih rezultata. U skladu sa tim, u literaturi se prevalencija krivičnih dela počinjenih od strane patoloških kockara kreće od 4\% do 90\% i/ili 21\%85\%, od kojih su 25\% do 39\% osuđeni (Adolphe et al., 2018; Perrone et al., 2013). I pored postojećih ograničenja, istraživački nalazi sugerišu da je veza između kockanja i nenasilnog kriminaliteta izraženija nego ona koja postoji u odnosu na nasilni kriminalitet. Nenasilni kriminalitet je najčešći vid kriminaliteta povezan sa kockanjem s ciljem finansiranja kockarskih aktivnosti (Arthur et al., 2014). Udeo ovih krivičnih dela kreće se između $65 \%$ i $89 \%$, a najčešća su finansijski motivisani kriminalitet: prevara, krađa, preprodaja psihoaktivnih supstanci, pronevere (Potenza, 2008 prema: Ashley \& Boehlke, 2012; Ladoucer et al., 1994 prema: Bjelajac, 2017). Veza kockanja i kriminalnih aktivnosti dokumentovana je u mnogim studijama tako da ćemo u nastavku rada predstaviti samo neke:

Opšta socijalna anketa „Fonda o kanadskom kockanju i ponašanju prema kockanju“ pokazalo je da se $64 \%$ ispitanika složilo da dostupnost igara na sreću dovodi do povećanja kriminala i 89\% izjasnilo da ne žele kockarnicu u svom kvartu. Percepciju da su mesta za igranje igara na sreću glavna lokacija za kriminalne aktivnosti zbog protoka ilegalnog novca kroz ove ustanove podržali su i policijski službenici (Smith et al., 2003).

Studija Blazcinskog i Mek Gonagija (Blaszczynski \& McConaghy, 1994b prema: Adolphe et al., 2018). Uzorak su činili kockari uključeni na tretman (na hospitalni tetman i u grupu anonimnih kockara) (n=306), (59\%) prijavilo da je učestvovalo $u$ kriminalnim aktivnostima da bi nastavilo da se kocka, (23\%) je osuđeno za ta dela. Distribucija kriminalnih aktivnosti: pronevera (29\%), trgovina drogom (2,9\%), provale (5\%) i krađa (4\%). 
Slične rezultate izveštava Mejer i Štedler (Meyer \& Stadler, 1999) na uzorku (n=437) patoloških kockara uključenih u tretman, (54\%) je učestvovalo u kriminalnim aktivnostima, (39,7\%) su činili prevare u cilju obezbeđivanja novca za kockanje.

Rezultati sprovedene studije u Kvebeku u Anonimnoj grupi kockara, 68\% uzorka je prijavilo kriminalne aktivnosti radi finansiranja kockanja i to: jedna trećina je izvestila da je ukrala novac od poslodavca da bi kockala, 10\% ispitanika je lažiralo dokumenta ili falsifikovalo potpise, $23 \%$ proneverilo, $33 \%$ prevarom došlo do novca, $18 \%$ podnelo lažne prijave poreza na dohodak ili zanemarilo plaćanje poreza na dohodak, $3 \%$ davalo lažne izjave osiguravajućim društvima (Ladoucer et al., 1994 prema: Smith et al., 2003).

Značajno je napomenuti i da istraživanja forenzičke populacije ukazuju da značajan udeo čine problematični i patološki kockari. U prilog tome govori i Hamburška studija (Study conducted in a Correctional institution in Hamburg) sprovedena 2009. godine bazirana na multi metodološkom pristupu sa ciljem da utvrdi prevalencu problema sa kockanjem u populaciji regionalnih zatvora, s jedne strane i istraži vezu između kockanja, kriminala i zatvora s druge strane. Uzorak je činilo $(\mathrm{n}=1047)$. Rezultati ukazuju da je $81 \%$ prestupnika ispunilo kriterijum za patološke kockare, $13 \%$ problematični, po kriterijumima DSM-IV, u više od polovine zatvorske populacije je prisutna istorija upotrebe PAS, najmanje ih je bilo u grupi problematičnih kockara. Upotreba heroina pre zatvora: samo $(4,4 \%)$ problematičnih kockara u poređenju sa $(21,7 \%)$ ostalih prestupnika, s druge strane, problematični kockari su imali znatno češce dugove od drugih prestupnika. Dugovi su dokumentovani u (81\%) problematičnih kockara i (60\%) ostalih. U pogledu krivičnih dela analiza je pokazala da je nasilno krivično delo $(37,1 \%)$ na prvom mestu, na drugom su krađe $(27,4 \%)$ i krivična dela protiv nacionalnog zakona o drogama (23,5\%). U komparaciji sa problematičnim kockarima i ostalim zatvorenicima postoje statistički značajne razlike u vrstama krivičnih dela koja su rezultirala zatvorom. Dok su nasilne zločine znatno češće izvršavali drugi zatvorenici (38,1\% u odnosu na: 24,4\%), krađe i pljačke i provale su bili češći uzroci zatvorske kazne među problematičnim kockarima. Može se zaključiti da je za skoro polovinu zatvorenika (46,7\%), njihova zatvorska kazna bila povezana sa kockarskim ponašanjem (Zurhold, Verthein \& Kalke, 2013).

Studija Turnera i saradnika sprovedena u saveznom zatvoru u Kanadi koja je istraživala povezanost problema sa kockanjem i kriminalne istorije na forenzičkoj populaciji ukupnog broja prestupnika $(\mathrm{n}=218)$, su 9,4\% prestupnika je sa teškim problemima sa kockanjem, $15,7 \%$ sa umerenim problemima. Disperzija krivičnih dela je: $15,1 \%$ je izvršilo finansijski kriminalitet, $14,6 \%$ krađu, 13,4\% razbojništvo i 20,3\% provale; $65 \%$ prestupnika sa teškim problemima sa kockanjem je izvestilo da je kockanje bilo povezano sa učinjenim krivičnim delom, 35\% kockanje kao deo kriminalnog načina života. Rezultati studije ukazuju da postoji korelacija između stepena problema sa kockanjem kod prestupnika i težine učinjenog krivičnog dela (Turner et al., 2009).

Na participaciju kriminalnih aktivnosti povezanih sa kockanjem prestupnika ukazuje i Studija o primarnoj motivaciji prestupnika sa problemom kocke i izvršenih 
finansijskih krivičnih dela u Australiji i Novom Zelandu obuhvatila je uzorak od 155 zasebnih dosijea, u koje je uključeno (289) optuženih, od kojih je (183) osuđeno zbog optužbi navedenih u studiji. Rezultati su ukazali da je kockanje (14,7\%) druga najčešća identifikovana motivacija osuđenih prestupnika nakon pohlepe $(27,3 \%)$. Najčešće prekršaje koje su počinili su pribavljanje finansijskih sredstava ili kredita obmanom (43\%) i prevare sa čekovima (43\%). Izvršioci većina prevara, koje su bile motivisane kockanjem, bili su zaposleni u vreme izvršenja krivičnog dela i skoro polovina je izvršena protiv poslodavca (Sakurai et al., 2003).

Na slične podatke ukazuje i Studija slučajeva pronevere zaposlenih u SAD između 2008. i 2012. godine ukazuje da je u trećini slučajeva krađe novca, počinilac imao problem sa kockanjem (Margaret International, 2013 prema: Binde, 2016).

Povezanost kockanja i kriminalnih aktivnosti dokumentovana je i u populaciji adolescenata. Prevalenca problematičnog kockanja među maloletnim delinkventima smeštenim na institucionalni tretman je oko (21\%), a od (18\% do 35\%) manifestuje simptome problematičnog kockanja, što je za 9 puta veća nego u opštoj adolescentskoj populaciji. Rezultati istraživanja na populaciji adolescenata koji ispunjavaju kriterijume za problematično i patološko kockanje ukazuju da je (42,4\%) problematičnih i patoloških kockara posuđivalo i kralo novac za kockanje (21\%) razmišljalo o činjenju krivičnih dela počinili nezakonite radnje zbog finansiranja kockanja, 24\% kralo novac od roditelja, (12\%) kralo novac van porodice (Bjelajac, 2017; Magoon,Gupta \& Derevensky, 2005). Još jedno istraživanje izvestilo je da su delinkventna i kriminalna ponašanja počinjena radi finansiranja kockanja oko 14\%, krađa novca od roditelja $12 \%$, krađa izvan kuce $5 \%$, prodaja tuđe imovine $6 \%$ (Temcheff, Pierre \& Derevensky, 2011).

U prilog složenosti veze između kockanja i kriminaliteta značajno je napomenuti da nisu sva krivična dela počinjena od patoloških kockara nužno povezana sa kockanjem. Priroda ovog odnosa može biti determinisana i drugim faktorima. Najpre, neki su počinili krivična dela pre početka „igračke karijere“, što ukazuje na spremnost preuzimanja rizika, kriminalne karijere i antisocijalne karakteristike ličnosti. Oko 9,3\% forenzičke populacije čine kockari sa impulsivnim osobinama ličnosti ranim ulaskom u kriminalne aktivnosti i rezidivizmom (May-Chahal et al., 2017).

$\mathrm{U}$ prilog tome govore i rezultati istaživanja sprovedenog u Rehabilitacionom centru za alkoholizam i droge u Australiji na uzorku ( $n=213$ ), disperzija po polu: $66,5 \%$ muškarci i 33,4\% žene, starosti od 16 do 64 godine. Rezultati ove studije ukazuju na neadekvatnu kontrolu impulsa sa povećanim nivoom hitnosti, nedostatkom predumišljaja i istrajnosti kao zajedničkog imenitelja kriminalnog ponašanja i upotrebe psihoaktivnih supstanci i problema sa kockanjem. Njih 28,6\% je prijavilo da se kocka, 6\% ranije imalo problem sa kockanjem, 46,2\% je zavisno od alkohola, $31,5 \%$ od PAS. Autori su zaključili da svi ispitanici imaju povišen nivo psihopatologije, traženja novina i smanjeni nivo usmerenosti i koopreativnosti (Mishra et al., 2011). 


\subsection{Kockanje i nasilje u porodici}

Dostupna literatura potvrđuje povezanost kockanja sa porodičnim i intimnim partnerskim nasiljem (Dowling et al., 2014; Shaw et al., 2007; Soumi et al., 2013). Najpre, partner i roditelji mogu biti izloženi ekonomskom nasilju. Primera radi „uzimanje“, kredita na partnerovo ime (često uz izgovor zajma za godišnji odmor), prisilno iskorišćavanje postojećih resursa roditelja kao garant za hipoteku čije su isplate izostale zbog kockanja. Nasilje može biti dvosmerno: stresori poput finansijskih teškoća, loša komunikacija, nepoverenje, hronični stres s jedne strane, mogu usmeriti nasilje članova porodice ka zavisniku, dok je s druge strane, intenzivna ljutnja, stres zbog „gubitaka“, kao i snižena tolerancija na frustraciju okidač verbalnog ili fizičkog nasilja zavisnika od kockanja (Balci \& Ayranci, 2005; Laursen et al., 2015; Korman et al., 2007). Rezultati istraživanja ukazuju da su nasilje i viktimizacija u porodici kockara više pravilo nego izuzetak. Preko jedne trećine pojedinaca koji su imali problem sa kockanjem oko $38 \%$ žrtve intimnog partnerskog nasilja, a $37 \%$ izvršioci. Šta više, $11 \%$ prestupnika u forenzičkoj populacijii izvršilaca intimnog partnerskog nasilja izveštavaju da je povezan sa kockanjem (Dowling et al., 2014). Zatim, sumirani rezultati studije $(n=122)$ problematična kockara koja su zatražila pomoć zbog kockanja, tako i porodičnog nasilja, ukazuju da je (52\%) prijavilo neki oblik porodičnog nasilja u poslednjih 12 meseci: (20\%) je prijavilo viktimizaciju, (10,8\%) samo činjenje nasilja, a (21,6\%) i činjenje i viktimizaciju (Laursen et al., 2015).

Do sličnih podataka u sprovedenom istraživanju dolazi i Afifi sa saradnicima (2010) na uzorku (248) probematična kockara. Autori ističu da (62,9\%) ispitanika izvestili o fizičkom napadu i seksualnoj prinudi u toke prethodne godine. Oko $(55,6 \%) \mathrm{su}$ počinili nasilje, dok je oko (45\%) izvestilo da je žrtva nasilja. Oko 32 ispitanika je izvestilo da je kockanje prethodilo nasilju (Afifi et al., 2010). Ovi rezultati podržavaju hipotezu da kockanje direktno ili indirektno dovodi do nasilja u porodici.

Upotreba alkohola i PAS su faktori komorbiditeta kockanja i nasilja (Roberts et al., 2016). Istraživanje na uzorku od 286 žena koje su potražile hitnu pomoć, 61 žena je prijavila nasilje od strane parnera, njih 23\% su bili zavisnici od kockanja, $71 \%$ zavisnici od kockanja i alkohola. Autori su zaključili da žena čiji partner ima problem sa kockanjem imaju 10,5 puta veću verovatnoću da će biti žrtve nasilja, a kada se radi o dualnoj zavisnosti, ta verovatnoća iznosi i do 50,4 puta (Muelleman et al., 2002).

Iako se većina podataka odnosi na intimno partnersko nasilje, postoje dokazi da nasiljem nisu izuzeta ni deca. U prilog tome govore podaci da je u oko $56 \%$ slučajeva izvršeno fizičko nasilje nad decom (Dowling et al., 2014).

\subsection{Rezultati istraživanja, statistički podaci: iskustva iz Srbije}

Da masovnost kockanja nije zaobišla ni našu zemlju, govore podaci Nacionalnog istraživanja o stilovima života stanovništva Srbije sprovedenog od strane Instituta za javno zdravlje „Milan Jovanović Batut“ 2014. godine. Rezultati istraživanja ukazuju da oko 3,7\% odrasle populacije poseduje rizik od nekog oblika kockanja, od 1,1\% do 
2,0\% poseduje umeren i viši rizik od kockanja (problematični kockari), dok o,3\% do 0,7\% poseduje visok rizik od kockanja (patološko kockanje). Nakon ekstrapolacije na populaciju u Srbiji starosne dobi od 18 do 64 godine, procenjuje se da problem kockanja varira između 51 i 93 hiljade ljudi, od čega su 14 do 33 hiljade patološki kockari (Kilibarda i sar., 2014).

U skladu sa prethodno navedenim modelom o direktnoj i indirektnoj vezi kockanja i kriminaliteta govori i istraživanje sprovedeno i u Srbiji. Naime, rezultati istraživanja potvrđuju prethodne rezultate da kockari pribegavaju prestupima kako bi vratili dugove i nadoknadili sredstva neophodna za servisiranje životnih troškova izgubljenih zbog kockanja. U oba slučaja kriminalne aktivnosti kockara predstavljaju pokušaj nadoknade gubitka zbog kockanja i/ili izbegavanja otkrivanja dugova od strane značajnih drugih (Arthur et al., 2014). U prilog tome govore rezultati israživanja sprovedenog u periodu od 2016. do 2019. godine, na uzroku $(n=90)$ zavisnika od kockanja, lečenih u Institutu za mentalno zdravlje. Oko 88,9\% zavisnika je izvestilo da je „pozajmljivalo“ novac iz kućnog budžeta, iz fonda zajedničke ušteđevine (66,7\%), prodavalo stvari i imovinu (43,3\%), koristilo čekove bez pokrića (16,7\%), zloupotrebilo kreditnu karticu članova porodice $(44,4 \%)$ „uzimalo“ novac od bračnog druga (28,9\%). Ovi prestupi su se rešavali u okviru porodice, što potvrđuje tezu da članovi porodice zaobilaze prijavu policiji nego rešavaju na internom nivou (Adolphe et al., 2018; Sakurai et al., 2003).

\subsection{Kockanje i saobraćajna delinkvencija}

Činjenica da je alkohol lako dostupan u kockarnicama sugeriše se da kockanje može biti katalizator povećane vožnje pod dejstvom alkohola, a samim tim i povećanim brojem saobraćajnih nesreća povezanih sa konzumiranjem alkohola. Mnoge kockarnice slede model „odmarališta“ i uključuju barove tako da kockari učestvujući u kockarskim aktivnostima, istovremeno uživaju i u konzumiranju alkohola. U prilog tome govore podaci sprovedenog istraživanja na nivou 31 županije u SAD u perodu od 1990. do 2000. godine povećanog broja saobraćajnih nesreća sa smrtnim ishodom za oko 9,2\% (Cotti \& Walker, 2010). S druge strane, neki autori prirodu ove veze sagledavaju kroz prizmu povećanja broja kockarnica koju prati i povećan broj učesnika u kockarskim aktivnostima, a koji su istovremeno i učesnici u saobraćaju. Kada se u obzir uzme i podatak da oko 70\% kockara ima problem i sa alkoholizmom, priroda odnosa postaje jasnija (Petry, Stinson \& Grant, 2005).

\subsection{Povezanost legalnog i ilegalnog kockanja}

S obzirom na to da je kockanje aktivnost koja je prisutna u svim kulturama i u većini delova sveta, samim tim i u većini zemalja, predstavlja slobodnu aktivnost pojedinca (Rayli \& Oei, 2004). Međutim, često se postavlja pitanje u kojoj meri društvo želi da kontroliše ili zabrani kockanje? Shodno tome, društvena reakcija prema kockanju se menjala od zabrane, pa do eksploatacije kockanja. Konkretno, danas se na globalnom nivou dešavaju krupne društveno-ekonomske promene, istovremeno, 
kockanje postaje način koji državama omogućava povećanje profita i dopunu budžeta (Walker \& Sobel, 2016).

U skladu sa tim, države ne samo da legalizuju, nego i proširuju spektar kockarskih aktivnosti u cilju prikupljanja što više sredstava (Hodgins \& Petry, 2016). Najpre, zagovornici legalnog kockanja ističu benefite po društvo, kao što su smanjenje ilegalnog kockanja i samim tim preusmeravanje njihovog profita u državne blagajne, jačanje lokalne ekonomije, turizma, zaposlenosti stanovništva. Zatim, zakonitost, kao i činjenica da su igre "fer" i da su postavljene kvote tačne. Međutim, legalizacija kockanja ne znači nužno i odsustvo ilegalnog kockanja. Ilegalno kockanje postaje unosno sredstvo za profit ljudi koji su spremni da prekrše zakon. Najpre, nudeći pogodnosti kojih u legalnom kockanju nema, kao što su: dobici bez oporezivanja (znajući da je zakonom kockar obavezan da plati porez na dobit), dok ilegalna mesta ne prijavljuju dobitak vlastima, što dovodi do manje verovatnoće da će igrač biti uhvaćen zbog utaje poreza, mogućnost klađenja na više uloga, duže radno vreme kockarnica, kockanje na kredit, upražnjavanje zakonom zabranjenih kockarskih aktivnosti (Forentzy \& Turner, 2009). Kriminalne grupe koje se nalaze na čelu ilegalnih kockarnica uključene su i u druge kriminalne aktivnosti (poput, utaje poreza, otmice, pranje novca, nameštanje utakmica, trgovine drogom, međunarodne prostitucije) (Banks \& Waugh, 2018).

Kolike su razmere ilegalnog kockanja, pokazuje i podatak da je u periodu između 1997. i 2002. godine samo u Kanadi zaplenjeno 2.034 ilegalnih mašina za kockanje, zajedno sa 1,23 miliona dolara u gotovini i 6,01 miliona dolara u svojini, a 2.069 osoba je optuženo za ilegalno kocanje (Moodie, 2002 prema: Arthur et al., 2014).

Ilegalno kockanje često ostaje neotkriveno jer su u njega umešani moćni pojedinci. Štaviše, olakšano je spregom sa vladajućim strukturama kroz korupciju visokih zvaničnika i policije (Arthur et al., 2014).

Podaci ukazuju da se organizacijom ilegalnog kockanja u svetu godišnje „opere" od 300 do 500 miliona dolara (Dadayan, 2016). Na taj način kockarska industrija stupa u uzajamni odnos sa globalnom ekonomijom jer se novac zarađen od ilegalnog kockanja uključuje u legalne tokove. Ovakva konstelacija odnosa doprinosi velikom ekonomskom gubitku jedne države, dok kriminalne organizacije stiču ogroman profit.

\section{ZAKLJUČNA RAZMATRANJA}

Sumirajući, pomenute teorije ukazuju na složenu vezu između kockanja i kriminaliteta. Najpre, rezultati istraživanja potvrđuju da je kockanje doprinoseći faktor kriminalnih aktivnosti. Finansijski motivisana krivična dela su najčešća vrsta kriminalnih aktivnosti kockara. Ona podrazumeva kriminalne aktivnosti da bi se obezbedila sredstva za nastavak kockanja kao i sredstva za nadoknadu sredstava za servisiranje životnih troškova izgubljenih kockanjem. Tu spadaju: krađe, prevare, pronevere. Varijabilni efekti koji doprinose izvršenju kriminalnih aktivnosti kockara ukazuju na doprinos i drugih faktora kao što su faktor ličnosti, upotreba alkohola i psihoaktivnih supstanci. Takođe, kada je reč o kockanju kao determinanti nasilja u 
porodici, može se zaključiti da je ono dvosmerno. U skladu s tim, prikazana istraživanja su pokazala da postoje određeni tipovi kriminaliteta na čiji nastanak deluje kockanje, što upućuje na pretpostavku da bi izvesne mere usmerene na smanjenje kockanja mogle delovati i na smanjenje zastupljenosti nekih vidova kriminaliteta. Postavlja se pitanje u kojoj meri društvo želi da kontroliše ili ograniči kockanje, s obzirom na to da kockanje postaje način koji državama omogućava povećanje profita i dopunu budžeta. Kada se radi o israživanjima u našoj zemlji, izostaju podaci o ovoj značnoj problematici. S toga se neizostavno nameće i zaključak da ova dva društvena fenomena zaslužuju sistematičnije istraživanje kako u drugim zemljama tako i u našoj. Ništa manje značajno, savremeno društvo treba da usmeri svoje resurse ka osmišljavanju programa tretmana prestupnika kod kojih su identifikovani problemi u vezi sa kockanjem, kao i programi prevencije zavisnosti od kockanja, koji će biti usmereni na celu populaciju, pojedince, rizične grupe i situacije.

\section{LITERATURA}

(1) Adolphe, A., Khatib, L., Van Golde, C., Gainsbury, S. M., \& Blaszczynski, A. (2019). Crime and gambling disorders: A systematic review. Journal of gambling studies, 35(2), 395-414. https://doi.org/10.1007/s10899-018-9794-7

(2) Afifi, T. O., Brownridge, D. A., MacMillan, H., \& Sareen, J. (2010). The relationship of gambling to intimate partner violence and child maltreatment in a nationally representative sample. Journal of Psychiatric Research, 44(5), 331-337. https://doi.org/10.1016/j.jpsychires.2009.07.010

(3) Arthur, J. N., Williams, R. J., \& Belanger, Y. D. (2014). The relationship between legal gambling and crime in Alberta. Canadian Journal of Criminology and Criminal Justice, 56(1), 49-84. https://doi.org/10.3138/cjccj.2012.E51

(4) Ashley, L. L., \& Boehlke, K. K. (2012). Pathological gambling: A general overview. Journal of psychoactive drugs, 44(1), 27-37. https://doi.org/10.1080/02791072.2012.662078

(5) Balci, Y. G., \& Ayranci, U. (2005). Physical violence against women: Evaluation of women assaulted by spouses. Journal of clinical forensic medicine, 12(5), 258-263. https://doi.org/10.1016/j.jcfm.2005.03.006

(6) Banks, J., \& Waugh, D. (2018). A taxonomy of Gambling-related crime International Gambling Studies. Journal International Gambling Studies 19(2), 339-357. https://doi.org/10.1080/14459795.2018.1554084

(7) Binde, P. (2016). Gambling-related embezzlement in the workplace: a qualitative study. International Gambling Studies, 16(3), 391-407.

https://doi.org/10.1080/14459795.2016.1214165

(8) Bjelajac, Ž. (2017). Patološko kockanje i kriminal. Kultura Polisa, 14(34), 185-201.

(9) Cook, S., Turner, N. E., Ballon, B., Paglia-Boak, A., Murray, R., Adlaf, E. M., ... \& Mann, R. E. (2015). Problem gambling among Ontario students: Associations with substance abuse, mental health problems, suicide attempts, and delinquent behaviours. Journal of Gambling Studies, 31(4), 1121-1134. https://doi.org/10.1007/s10899-014-9483-0

(10) Cotti, C. D., \& Walker, D. M. (2010). The impact of casinos on fatal alcohol-related traffic accidents in the United States. Journal of Health Economics, 29(6), 788796. https://doi.org/10.1016/j.jhealeco.2010.08.002 
(11) Dadayan, L. (2016). State Revenues from Gambling Shrinking. The Council of State Goverments, 399-406.

(12) Dowling, N. A., Suomi, A., Jackson, A. C., \& Lavis, T. (2015). Problem Gambling Family Impacts: Development of the Problem Gambling Family Impact Scale. Journal of Gambling Studies, 32(3), 935-955. https://doi.org/10.1007/s10899-015-9582-6

(13) Dowling, N., Suomi, A., Jackson, A., Lavis, T., Patford, J., Cockman, S., ... \& Harvey, P. (2016). Problem gambling and intimate partner violence: A systematic review and meta-analysis. Trauma, Violence, \& Abuse, 17(1), 43-61. https://doi.org/10.1177/1524838014561269

(14) Folino, J. O., \& Abait, P. E. (2009). Pathological gambling and criminality. Current Opinion in Psychiatry, 22(5), 477-481.

https://doi.org/10.1097/YCO.obo13e32832ed7ed

(15) Forentzy, P., \& Turner, N. (2009). Gambling and organized crime - a review of the Yournal Gambling issues, 23(2), 111-155. http://dx.doi.org/10.4309/jgi.2009.23.6

(16) Hodgins, D. C. \& Petry, N. M. (2016). The world of Gambling: The National Gambling Experiences series. Addiction, 111(9), 1516-1518. https://doi.org/10.1111/add.13445

(17) Kilibarda, B., Mravčik, V., Sieroslavski, J., Gudelj Rakić, J., \& Sebastian Martens, M. (2014). Nacionalno istraživanje o stilovima života stanovnistva Srbije. Beograd: Institut za javno zdravlje Srbije „Dr Milan Jovanović Batut”.

(18) Korman, L. M., Collins, J., Dutton, D., Dhayananthan, B., Littman-Sharp, N., \& Skinner, W. (2007). Problem Gambling and Intimate Partner Violence. Journal of Gambling Studies, 24(1), 13-23. https://doi.org/10.1007/s10899-007-9077-1

(19) Lambie, I ., \& Randell, I. (2013). The impact of incarceration of juvenile offenders. Clinical Psychology Review, 33(3), 448-459. https://doi.org/10.1016/j.cpr.2013.01.007

(20) Laursen, B., Plauborg, R., Ekholm, O., Larsen, C. V. L., \& Juel, K. (2015). Problem Gambling Associated with Violent and Criminal Behaviour: A Danish PopulationBased Survey and Register Study. Journal of Gambling Studies, 32(1), 25-34. https://doi.org/10.1007/s10899-015-9536-z

(21) Lind, K., Kääriäinen, J., \& Kuoppamäki, S.-M. (2015). From problem gambling to crime? Findings from the finnish national police information system. Journal of Gambling Issues, 30, 98-123. http://dx.doi.org/10.4309/jgi.2015.30.10

(22) Magoon, M. E., Gupta, R., \& Derevensky, J. (2005). Juvenile Delinquency and Adolescent Gambling. Criminal Justice and Behavior, 32(6), 690-713. https://doi.org/10.1177/0093854805279948

(23) May-Chahal, M., Humphreys,L., Clifton, A., Francis,B., \& Reith, G. (2017). Gambling Harm and Crime Careers. Journal of Gambling Studies, 33(1), 65-84. https://doi.org/10.1007/s10899-016-9612-z

(24) Mestre-Bach, G., Steward, T., Granero, R., Fernández-Aranda, F., Mena-Moreno, T., Vintró-Alcaraz, C., ... \& Jiménez-Murcia, S. (2020). Dimensions of impulsivity in Gambling Disorder. Scientific Reports, 1O(1), 1-11. https://doi.org/10.1038/s41598019-57117-z

(25) Meyer, G., \& Stadler, M. A. (1999). Criminal Behavior Associated with Pathological Gambling. Journal of Gambling Studies, 15(1), 29-43. https://doi.org/10.1023/A:1023015028901

(26) Mishra, S., Lalumière, M. L., Morgan, M., \& Williams, R. J. (2011). An Examination of the Relationship Between Gambling and Antisocial Behavior. Journal of Gambling Studies, 27(3), 409-426. https://doi.org/10.1007/s10899-010-9217-x

(27) Muelleman, R. L., DenOtter, T., Wadman, M. C., Tran, T. P., \& Anderson, J. (2002). Problem gambling in the partner of the emergency department patient as a risk 
factor for intimate partner violence. The Journal of emergency medicine, 23(3), 307-312. https://doi.org/10.1016/So736-4679(02)o0543-7

(28) Petry, N. M., Stinson, F. S., \& Grant, B. F. (2005). Comorbidity of DSM-IV Pathological Gambling and Other Psychiatric Disorders: Results From the National Epidemiologic Survey on Alcohol and Related Conditions. The Journal of Clinical Psychiatry, 66(5), 564-574. https://doi.org/10.4088/JCP.v66no504

(29) Podgornik, N., \& Kovačić, A. (2013). The Influence of gambling on criminal activities in the region of Goriška. Innovative Issues and Approaches in Social Sciences, 6(1),135-154.

(30) Potenza, M. N., Steinberg, M. A., McLaughlin, S. D., Wu, R., Rounsaville, B. J., \& O'Malley, S. S. (2001). Gender-related differences in the characteristics of problem gamblers using a gambling helpline. American Journal of Psychiatry, 158(9), 1500-1505. https://doi.org/10.1176/appi.ajp.158.9.1500

(31) Rayli, N., \& Oei, T.P. (2004). Role of Culture in Gambling and Problem Gambling. Clinical Psychology Review, 23(8), 1087-1114. https://doi.org/10.1016/j.cpr.2003.09.005

(32) Roberts, A., Coid, J., King, R., Murphy, R., Turner, J., Bowden-Jones, H., ... \& Landon, J. (2016). Gambling and violence in a nationally representative sample of UK men. Addiction, 111(12), 2196-2207. https://doi.org/10.1111/add.13522

(33) Rudd, C., \& Thomas, S. D. M. (2015). The Prevalence, Mental Health and Criminal Characteristics of Potential Addiction. Problem Gamblers in a Substance Using Treatment Seeking Population. International Journal of Mental Health and Addiction 14(5), 700-714. https://doi.org/10.1007/s11469-015-9604-8

(34) Shaffer, H. J., \& Korn, D. A. (2002). Gambling and related mental disorders: a public health analysis. Annual Review of Public Health, 23(1), 171-212. https://doi.org/10.1146/annurev.publhealth.23.100901.140532

(35) Shaw, M. C., Forbush, K. T., Schlinder, J., Rosenman, E., \& Black, D. W. (2007). The Effect of Pathological Gambling on Families, Marriages, and Children. CNS Spectrums, 12(08), 615-622. https://doi.org/10.1017/S1092852900021416

(36) Smith, G., \& Simpson, R. (2014). Gambling addiction defence on trial: Canadian expert witness perspectives. International Journal of Criminology and Sociology, $3,319-326$.

(37) Stitt, B. G., Nichols, M., \& Giacopassi, D. (2003). Does the Presence of Casinos Increase Crime? An Examination of Casino and Control Communities. Crime \& Delinquency, 49(2), 253-284. https://doi.org/10.1177/0011128702251058

(38) Subotin, M. (2018). Uticaj socijalne patologije na bezbednost države sa osurtom na krivičnopravnu Regulativu (Doktorska disertacija). Novi Sad. Univezitet u Novom Sadu-Pravni fakultet za privredu i pravosuđe.

(39) Suomi, A., Jackson, A. C., Dowling, N. A., Lavis, T., Patford, J., Thomas, S. A., ... \& Cockman, S. (2013). Problem gambling and family violence: family member reports of prevalence, family impacts and family coping. Asian Journal of Gambling Issues and Public Health, 3(1), 1-15. https://doi.org/10.1186/2195-3007-3-13

(40) Temcheff C., E., Pierre, R. A., \& Deverensky, J. (2011). Youth Gambling and Delinquency: Legislative and Social Policy Implications. Gaming Law Review and Economics, 15(9), 539-552. https://doi.org/10.1089/glre.2011.15907

(41) Tse, S., Hong, S. I., Wang, C. W., \& Cunningham-Williams, R. M. (2012). Gambling behavior and problems among older adults: a systematic review of empirical studies. Journals of Gerontology Series B: Psychological Sciences and Social Sciences, 67(5), 639-652. https://doi.org/10.1093/geronb/gbso68

(42) Turner, N. E., Preston, D. L., McAvoy, S., \& Gillam, L. (2013). Problem Gambling Inside and Out: The Assessment of Community and Institutional Problem Gambling 
in the Canadian Correctional System. Journal of Gambling Studies, 29(3), 435-451. https://doi.org/10.1007/s10899-012-9321-1

(43) Turner, N. E., Preston, D. L., Saunders, C., McAvoy, S., \& Jain S. (2009). The Relationship of Problem Gambling to Criminal Behavior in a Sample of Canadian Male Federal Offenders. Journal of Gambling Studies, 25(2), 153-169. https://doi.org/10.1007/s10899-009-9124-1

(44) Walker, D. M., \& Sobel, R. S. (2016). Social and economic impacts of gambling. Current Addiction Reports, 3(3), 293-298. https://doi.org/10.1007/s40429-016-0109-8

(45) Zurhold, H., Verthein, U., \& Kalke, J. (2014). Prevalence of problem gambling among the prison population in Hamburg, Germany. Journal of Gambling Studies, 3O(2), 309-319. https://doi.org/10.1007/s10899-013-9361-1

\section{Elektronski izvori:}

(46) Aborn, R. M. (2005). Gambling: Who's really at risk? The connection between gambling and crime. Dostupno na https://constantinecannon.com/wpcontent/uploads/2017/o9/GamblingReport.pdf, pristupljeno: maj, 2020

(47) Binde, P. (2009). Gambling motivation and involment.A reviev of Social Science reaserch. The Swedish Nationa Institute of Public Health. Dostupno na: https://prism.ucalgary.ca/bitstream/handle/1880/51055/R2009-20-gamblingmotivation-a-review.pdf/, pristupljeno: jun, 2020

(48) Kryszajtys, D. T., \& Matheson, F. I. (2017): Problem gambling and Crime and its Costs. Gambling Research Exchange Ontario, dostupno na:

https://www.greo.ca/Modules/EvidenceCentre/files/Kryszajtys\%20and\%20Mathes on\%20(2017)\%20Problem\%20gambling\%20and\%20crime\%20and\%20its\%20costs .pdf pristupljeno: jun, 2020

(49) Perrone, S., Jansons, D., \& Morrison, L. (2013). Problem gambling and the criminal justice system. Problem gambling and the criminal justice system. Dostupno na: Downloads/Problem-Gambling-Criminal-Justice\%20(3).pdf, pristupljeno: maj, 2020

(50) Sakurai, Y., Smith, R., \& Graycar, A. (2003). Gambling as a Motivation for the Commission of Financial Crime. Trends and Issues in Crime and Criminal Justice 256, dostupno na: https://www.aic.gov.au/sites/default/files/202005/tandi256.pdf, pristupljeno: maj, 2020

(51) Smith, G. J., Wynne, H., \& Hartnagel, T. F. (2003). Examining police records to assess gambling impacts: A study of gambling-related crime in the City of Edmonton: A study prepared for TheAlberta Gaming Research Institute. Edmonton, AB: Alberta Gaming Research Institute. Dostupno na:http://www.hawaiifamilyforum.org/wp-content/uploads/2015/o1/AlbertaCanada-Study-on-Crime-and-Gambling-2003.pdf pristupljeno: jun,2020 


\section{GAMBLING AS A CRIMINOGENIC FACTOR}

The aim of this paper is to consider the relationship between gambling as an already developed addiction on the one hand and criminal behavior on the other. The paper first presents the theoretical views and understandings of the nature of the relationship between gambling and crime, as well as several models that show the extent to which gambling contributes to a particular criminal behavior. Data from various studies confirm that the criminogenic effect of gambling can be distinguished in certain types of crime. The most common types of gambling-related crimes are financially motivated crimes such as theft, fraud, embezzlement, domestic violence, juvenile and traffic delinquency. Consideration of the results also indicates a complex relationship between gambling and crime, and that this criminogenic factor should be paid more attention, especially in domestic criminological research.

KEY WORDS: gambling / criminogenic factor / crime / violence 